\title{
ANALISIS PERBANDINGAN TEMPERATUR DALAM DAN LUAR SERTA KELEMBABAN RELATIF PADA MESIN PENETAS TELUR TENAGA LISTRIK
}

\author{
Zulhajjii $^{1}$ \\ ${ }^{1}$ Teknik Elektro Fakultas Teknik, Universitas Negeri Makassar \\ ajjimuda@yahoo.co.id
}

\begin{abstract}
ABSTRAK
Tujuan penelitian ini adalah untuk mengetahui besar perbandingan temperatur luar dan dalam serta kelembaban udara pada mesin penetas telur tenaga listrik. Dalam rangka mencapai tujuan dan target yang telah ditetapkan itu penelitian ini dirancang dalam dalam tiga tahap. Tahap pertama, pembuatan mesin penetas telur, tahap kedua uji coba dan tahap ketiga analisis. Berdasarkan data hasil pengukuran dan dianlisis diperoleh gambaran bahwa temperatur dan kelembaban pada mesin penetas tersebut sangat berpengaruh terhadap kualitas penetasan telur ayam kampung. Penelitian ini menggunakan metode eksperimen dan dilakukan dua kali percobaan memasukkan telur untuk ditetaskan. Tahap pertama pengujian dan pengukuran diperoleh data rata-rata temperatur luar $28,5 \mathrm{C}^{\circ}$, didalam $38,2 \mathrm{C}^{\circ}$ dan kelembaban udara didalam ruang penetasan $56,0 \%$, sedangkan tahap kedua pengujian dan pengukuran diperoleh data rata-rata temperatur luar $28,42 \mathrm{C}^{\circ}$, didalam $38,0 \mathrm{C}^{\circ}$ dan kelembaban udara didalam ruang penetasan $56,0 \%$. Sehingga dapat disimpulkan bahwa jika perbandingan temperatur luar dan dalam pada mesin penetas harus seimbang sampai hari ke-21 penetasan. Dalam artian bahwa jika temperatur luar naik, maka temperatur dalam mesin penetas harus turun, dengan besaran yang relatif sama. Demikian juga kelembaban udara didalam harus memiliki perbandingan yang relatif sama agar diperoleh proses penetasan yang sempurna yaitu antara $50 \%-60 \%$.
\end{abstract}

Kata Kunci: Temperatur Luar Dan Dalam, Kelembaban Udara, Mesin Penetas Telur.

\section{COMPARISON ANALYSIS OF INTERNAL AND EXTERNAL TEMPERATURE AND RELATIVE HUMIDITY ON ELECTRIC POWERED EGGS INTRODUCTION}

\begin{abstract}
The purpose of this study was to determine the ratio of the outside and inside temperature and humidity of the electric egg incubator. In order to achieve the goals and targets that have been set, this research was designed in three stages. The first stage, the manufacture of an egg incubator, the second stage of testing and the third stage of analysis. Based on the measurement and analysis data, it is obtained that the temperature and humidity of the incubator greatly affect the quality of the hatching of free-range chicken eggs. This study used an experimental method and carried out two experiments to insert eggs to be incubated. The first stage of testing and measurement obtained data on an average outside temperature of $28.5 \mathrm{Co}$, inside 38.2Co and humidity in the hatch room 56.0\%, while the second stage of testing and measurement obtained data on an average outside temperature of $28.42 \mathrm{Co}$, inside 38 0.0Co and the humidity in the hatching room is $56.0 \%$. So it can be concluded that if the ratio of the outside and inside temperatures on the incubator must be balanced until the 21st day of hatching. In the sense that if the outside temperature increases, the temperature in the incubator must decrease, by a relatively equal amount. Likewise, the humidity of the air inside must have a relatively equal ratio in order to obtain a perfect hatching process, which is between $50 \%$ - $60 \%$.
\end{abstract}

Keyword: Outside And Inside Temperature, Air Humidity, Egg Incubator. 


\section{PENDAHULUAN}

Mesin penetas telur dengan menggunakan pemanas dari bola lampu telah banyak digunakan baik oleh industri sekala kecil maupun besar, juga oleh masyarkat umumnya, keberhasilan penetasan telur ayam sangat dipengaruhi oleh temperatur dan kelembaban, dimana temperatur yang baik untuk penetasan telur ayam berkisar antara $36^{\circ} \mathrm{C}$ sampai dengan $40^{\circ} \mathrm{C}$, dengan kelembaban relatif antara $50 \%$ sampai dengan $60 \%$. Namun tidak semua pengguna mesin penetas telur ayam mengetahui betul tentang temperatur dan kelembaban udara yang sesuai dengan telur yang mau ditetaskan, agar proses penetasan berjalan dengan baik dan normal. Namun untuk mendapatkan temperatur yang merata dan kelembaban yang baik untuk penetasan dibutuhkan penempatan sumber kalor yang terukur dan merata didalam ruang penetasan. Temperatur dan kelembaban sangat erat hubungannya dengan perubahan kalor yang terjadi pada mesin penetas, baik didalam maupun di luar mesin penetas. Semakin tinggi temperatur di luar tentu sangat berpengaruh temperatur di dalam mesin penetas. Beberapa studi literatur telah dilakukan terhadap beberapa penelitian yang berhubungan dengan penetasan telur ayam terutama yang berhubungan dengan temperatur di luar dan dalam serta kelembaban udara pada mesin penetas telur ayam. Temperatur dan kelembaban dalam mesin penetas harus stabil untuk mempertahankan kondisi telur agar tetap baik selama proses penetasan, telur akan banyak menetas jika berada pada temperatur antara $36-40^{\circ} \mathrm{C}$, Embrio tidak toleran terhadap perubahan temperatur yang drastis.

Kelembaban didalam mesin penetas sebaiknya diusahakan tetap pada range $50-60 \%$, Temperatur yang terlalu tinggi akan menyebabkan kematian embrio ataupun abnormalitas embrio, sedangkan kelembaban mempengaruhi pertumbuhan normal dari embrio. Perubahan temperatur luar dan kelembaban relatif pada proses penetasan telur ayam kampung, akan mempengaruhi proses penetasan telur secara signifikan, sehingga perlu penelitian untuk meneliti pengaruh temperatur luar dan dalam serta kelembaban relatif pada mesin penetas telur tenaga listrik yang terbuat dari bahan tripleks dengan ketebalan 9 millimeter.

\section{Penetasan Telur}

Upaya bangsa unggas dalam mempertahankan populasinya, yaitu dengan bertelur.Telur tersebut kemudian ditetaskan, baik secara alami maupun buatan hingga melahirkan individu baru [1]. a. Jenis Alat Penetas Buatan.

Dari berbagai alat penetas dapat dibedakan menjadi dua alat penetas berdasarkan dari cara penggunaannya,yaitu :

1) Alat Tetas Konvensional

Alat tetas konvensional merupakan alat penetas yang menggunakan sumber panas dari matahari dengan penyimpanan panas berupa sekam. Alat ini sudah sejak lama dikenal ditengah masyarakat. Sejarah konon alat ini pertama kali digunakan oleh penetas telur di daerah Bali yang kemudian penggunaannya mulai menyebar ke berbagai tempat.

2) Mesin Tetas/Alat Penetas Telur

Mesin tetas ini merupakan salah satu media yang berupa peti, lemari atau box dengan konstruksi yang sedemikian rupa sehingga panas di dalamnya tidak terbuang. Suhu di dalam peti/lemari/box dapat diatur sesuai ukuran derajat panas yang dibutuhkan selama periode penetasan. Prinsip kerja penetasan telur dengan mesin tetas ini sama dengan induk unggas. Keberhasilan penetasan telur dengan mesin tetas akan tercapai bila memperhatikan beberapa perlakuan sebagai berikut :

a) Telur ditempatkan dalam mesin tetas dengan posisi yang tepat.

b) Panas (suhu) dalam ruangan mesin tetas selalu dipertahankan sesuai dengan kebutuhan.

c) Telur dibolak-balik 3 kali sehari selama proses pengeraman.

d) Ventilasi harus sesuai agar sirkulasi udara di dalam mesin tetas berjalan dengan baik.

e) Kelembapan udara di dalam mesin tetas selalu dikontrol agar sesuai untuk perkembangan embrio di dalam telur.

Dengan memperhatikan beberapa perlakuan tersebut, mesin tetas/alat penetas dapat dibedakan atas beberapa tipe sebagai berikut :

1) Berdasarkan penyebab adanya panas dalam ruangan.

- Alat penetas/mesin penetas dengan udara panas.

- Alat penetas/mesin penetas dengan air panas.

2) Berdasarkan sumber alat pemanas.

- Alat penetas dengan listrik (pemanas listrik).

- Alat penetas dengan lampu minyak.

- Alat penetas kombinasi (dengan pemanas listrik dan lampu minyak).

3) Berdasarkan cara pengaturan kelembapan udara.

- Alat penetas dengan cara kering (tidak dilengkapi dengan bak air).

- Alat penetas dengan cara basah (dilengkapi dengan bak air). 
4) Berdasarkan cara penyediaan ruangan tempat peletakan telur.

- Alat penetas dengan tipe ruang kotak (menggunakan satu rak telur, sehingga telur yang dapat ditetaskan juga terbatas).

- Alat penetas dengan tipe ruang kabinet (menggunakan banyak rak sehingga dapat menampung telur yang cukup banyak).

\section{Syarat-syarat penetasan telur :}

a. Suhu dan Perkembangan Embrio

Embrio dalam telur unggas akan cepat berkembang selama suhu telur berada pada kondisi yang sesuai dan akan berhenti berkembang jika suhunya kurang dari yang dibutuhkan.

Suhu yang dibutuhkan untuk penetasan telur setiap unggas berbeda-beda. Suhu untuk perkembangan embrio dalam telur ayam antara $38,33^{\circ}-40,55^{\circ} \mathrm{C}$ ( 101o-105o F), itik 37,78o $39,45^{\circ} \mathrm{C}\left(100^{\circ}-103^{\circ} \mathrm{F}\right)$, puyuh $39,5^{\circ} \mathrm{C}\left(102^{\circ} \mathrm{F}\right)$, dan wallet $32,22^{\circ}-31^{\circ} \mathrm{C}\left(90-96^{\circ} \mathrm{F}\right)$. Untuk itu, sebelum telur tetas dimasukan ke dalam bok penetasan suhu ruang tersebut harus sesuai dengan yang dibutuhkan [2].

b. Kelembaban.

Selama penetasan berlangsung, diperlukan kelembaban udara yang sesuai dengan perkembangan dan pertumbuhan embrio, seperti suhu dan kelembaban yang umum untuk penetasan telur setiap jenis unggas juga berbedabeda. Bahkan, kelembapan pada awal penetasan berbeda dengan hari-hari selanjutnya. Kelembapan untuk telur pada saat awal penetasan sekitar 52\%-55\% dan menjelang menetas sekitar $60 \%-70 \%$, Itik pada minggu pertama $70 \%$ dan minggu selanjutnya $60 \%-65 \%$, puyuh minggu pertama 55\%-70\% selanjutnya $65 \%$ dan walet $65 \%-70 \%$ pada setiap minggunya [3].

\section{c. Ventilasi}

Dalam perkembangan normal, embrio membutuhkan oksigen (O2) dan mengeluarkan karbondioksida $(\mathrm{CO} 2)$ melalui pori-pori kerabang telur. Untuk itu, dalam pembuatan alat penetas telur/mesin tetas harus diperhatikan cukup tidaknya oksigen yang ada dalam bok/ruangan, karena jika tidak ada oksigen yang cukup dalam bok/ruangan dikhawatirkan embrio gagal berkembang [4].

\section{d. Waktu Penetasan Telur.}

Penetasan telur biasanya diperlukan waktu sekitar 20-23 hari untuk menetas dengan sempurna (sehat), pembagian waktu dapat dijabarkan sebagai berikut [5]:
Dalam proses penetasan telur ayam dengan inkubator bisanya memerlukan waktu antara 21-22 hari dengan tahapan seperti berikut: Hari pertama : Pada pagi hari, masukkan telur yang sudah siap pada mesin dengan sudut sekitar $40^{\circ}$, bagian lancip dibawah dan bagian tumpul diatas dan tutup pintu rapat-rapat sampai dengan hari ke-2. Hari ke-3: Putar telur 3x sehari dipagi hari, siang dan sore (Jangan keluarkan telur dari mesin). Hari ke-4: Buka ventilasi $1 / 4$ bagian selama 15 menit untuk mendinginkan telur setelah itu balik telur. Hari ke-5: Buka ventilasi 1/2 bagian dan mulailah membalik telur. Hari ke-6: Buka ventilasi $3 / 4$ bagian dan balik telur. Hari ke-7: Balik telur dan buka ventilasi seluruhnya dan mulailah menyortir telur yang kosong. Hari Hari ke-14: Balik telur dan sortir lagi bibit yang mati (Bibit yang mati akan terlihat cairan atau darah sedangkan yang hidup akan terlihat titik yang bercabang). ke 8 s.d 13: Balik telur dan dinginkan. Hari ke 15 s.d 17: Balik telur dan dinginkan. Hari ke-18 : Balik telur dan pastikan mesin masih dalam keadaan tertutup. Hari ke-19 : Ketika telur mulai retak mulailah menambah kelembaban udara pada mesin tetas dengan cara menggantungkan kain basah disekitar telur (Jangan sampai menetesi pipa pengantar panas). Hari ke-20: Ketika telur sudah mulai menetas tutup kaca pengintai dengan kertas atau kain hitam. Hari ke-21 : Keluarkan bak air dan kain dari mesin karena telur sudah menetas. Hari ke-22 : Mulailah memindahkan anak ayam yang telah menetas ke tempat induk buatan.

\section{Thermostat Penetas Telur}

Ada 2 jenis thermostat yang biasa digunakan pada mesin penetas telur, yaitu: Thermostat Kapsul dan Thermostat Digital.

\section{a. Thermostat Kapsul /Wafer}

Mayoritas mesin penetas telur menggunakan thermostat tipe ini karena harganya sangat terjangkau (murah) dan mudah pengoperasiannya.Thermostat sederhana ini bekerja secara elektro-mekanial yang memanfaatkan prinsip pemuaian cairan eter di dalam sebuah Kapsul. Jika Anda perhatikan pada gambar 1, yang disebut Kapsul adalah benda berbentuk Lingkaran berwarna hitam. Ketika suhu mulai memanas, kapsul akan mengembang dan menekan mikroswitch(Limitswitch) untuk mematikan lampu pemanas. Dan sebaliknya, pada saat suhu mulai mendingin, kapsul akan mengempis dan kemudian memicu mikroswitch untuk kembali menyalakan lampu pemanas. 


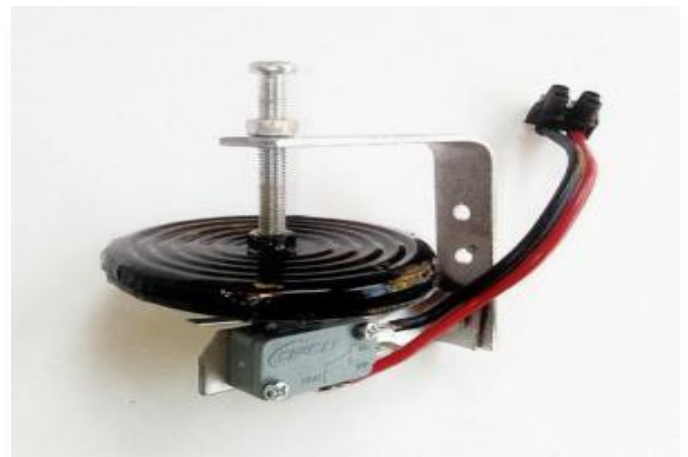

Gambar 1. Thermostat Kapsul/Wafer

Agar bekerja pada suhu yang diinginkan, cara mensetting thermostat ini sangatlah mudah. Putar sekrupnya secara perlahan untuk mengatur jarak antara kapsul dengan mikroswitchnya. Jika kapsul bergerak mendekati mikroswitch maka suhunya akan disetting rendah, dan sebaliknya suhu akan disetting tinggi pada saat kapsul mulai menjauhi mikroswitch. Untuk Satu Paket thermostat kapsul terdiri dari:

- Rangka/dudukan

- Kapsul

- Microswitch(Limitswitch

- Kabel

\section{Thermostat Digital}

Thermostat ini berbentuk sebuah modul yang bekerja secara digital dengan bantuan probe yang berfungsi sebagai sensor suhu. Kelebihan thermostat ini telah dilengkapi dengan thermometer dan bisa difungsikan dalam mode pemanas atau pendingin, sebagaimana gambar 2 . Di bawah ini. Sedangkan Untuk mengaktifkannya, thermostat penetas telur ini memerlukan tegangan DC 12 volt dari adaptor.

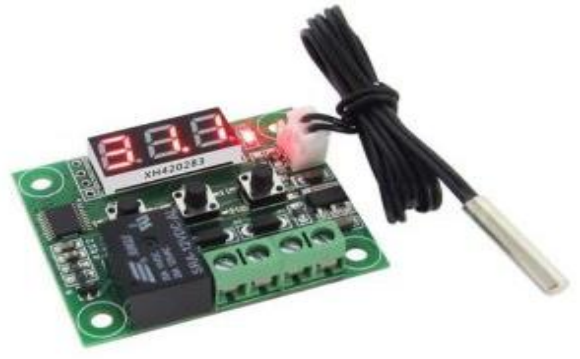

Gambar 2. Thermostat Digital

\section{Lampu Lampu Pijar}

a. Karakteristik

Jenis lampu incandenscent ini biasa disebut lampu pijar, lampu pijar akan memancarkan cahaya ketika ada arus listrik melewati filamen kawat pijar pada lampu dan kemudian memanasi filamen tersebut. Pembuatan lampu pijar juga didasarkan pada beberapa faktor, yaitu temperatur filamen, campuran gas yang di isikan, efficacy
(im/W), dan umur lampu. Tahanan filamen tungsten akan semakin tinggi jika temperatur naik, sehingga kenaikan tegangan akan mengakibatkan menaiknya tahanan yang juga akan terjadi sedikit kenaikan arus yang mengalir. Tahanan filamen kira-kira seperempat belas dari keadaan temperatur normal dalam keadaan dingin. Salah satu yang perlu diperhatikan dalam karakteristik lampu pijar ini adalah pengaruh perubahan tegangan terhadap lampu [6].

\section{b. PrinsipKerja}

Prinsip kerja dari lampu pijar tersebut adalah dengan cara menghubung singkat listrik pada filamen carbon (C) sehingga terjadi arus hubung singkat pada yang mengakibatkan timbul panas. Panas yang terjadi dibuat hingga suhu tertentu sampai mengeluarkan cahaya

\section{c. Kontruksi}

Jenis lampu ini lebih dikenal dengan sebutan lampu DOP, termasuk juga lampu yang ditemukan pertama kali oleh Tomas Alva Edison. Lampu incandescent terdiri atas beberapa bagian utama yaitu bulb atau bola lampu, base lamp, dan filamen kawat pijar.

\section{METODE PENELITIAN}

Jenis penelitian ini merupakan penelitian eksperimen. Dengan demikian data yang akan diteliti adalah data-data yang diperoleh dari hasil pengukuran melalui percobaan di laboratorium. Hasil penelitian ini bertujuan agar diperoleh gambaran besar perbandingan temperatur luar dan dalam serta kelembaban relatif pada mesin penetas telur tenaga listrik tersebut, agar diperoleh proses penetasan telur yang maksimal (telur yang ditetaskan menetas semua).Variabel dalam penelitian ini terdiri atas 2 variabel, yakni temperatur luar/dalam dan kelembaban relatif pada mesin penetas telur tenaga listrik.Teknik pengumpulan data yang dilakukan dalam penelitian ini adalah: Data yang akan digunakan dalam penelitian ini merupakan data temperatur dan kelembaban relatif yang diperoleh secara langsung melalui hasil pengukuran dan studi literatur adalah suatu teknik yang digunakan untuk memperoleh data-data atau sumber-sumber yang berhubungan dengan topik yang diteliti. Teknik analisis data yang akan digunakan dalam penelitian ini adalah analisis deskriptif digunakan untuk menganalisis data dengan cara mendeskripsikan atau menggambarkan data yang diperoleh dari hasil pengukuran di laboratorium dengan melalui percobaan.

\section{HASIL DAN PEMBAHASAN}

Penelitian yang dilaksanakan dengan menggunakan mesin penetas telur ayam, dimana 
mesin penetas tersebut terbuat dari bahan tripleks $9 \mathrm{~mm}$. Ukuran $30 \mathrm{x} 40 \mathrm{~cm}$ dengan jumlah bolah lampu pijar 3 buah, masing-masing daya 5 Watt sehingga dapat menetaskan 50 butir telur. Berdasarkan penelitian diperoleh hasil penelitian sebagai berikut :

TABEL 1. HASIL PENGUKURAN HARI KE-1

\begin{tabular}{cccc}
\hline \multirow{2}{*}{$\begin{array}{c}\text { Waktu } \\
(\text { Jam) }\end{array}$} & \multicolumn{2}{c}{$\begin{array}{c}\text { Temperatur } \\
\left(\mathbf{C}^{\mathbf{o}}\right)\end{array}$} & $\begin{array}{c}\text { Kelembaban } \\
(\boldsymbol{\%})\end{array}$ \\
\cline { 2 - 3 } & Luar & Dalam & 79 \\
\hline 7.00 & 26,5 & 36,5 & 75 \\
8.00 & 27,1 & 36,8 & 70 \\
9.00 & 28,1 & 37,8 & 62 \\
10.00 & 29,0 & 38,5 & 61 \\
11.00 & 29,9 & 38,8 & 62 \\
12.00 & 30,4 & 38,8 & 58 \\
13.00 & 30,7 & 39,0 & 60 \\
14.00 & 30,9 & 39,0 & 55 \\
15.00 & 30,9 & 38,5 & 56 \\
16.00 & 31,0 & 39,0 & 58 \\
17.00 & 30,0 & 39,0 & 60 \\
18.00 & 30,1 & 39,0 & 64 \\
19.00 & 29,9 & 39,0 & 66 \\
20.00 & 29,5 & 39,0 & 67 \\
21.00 & 29,1 & 39,0 & 68 \\
22.00 & 28,8 & 39,0 & 69 \\
23.00 & 28,0 & 39,0 & 70 \\
24.00 & 27,8 & 38,5 & 71 \\
1.00 & 27,0 & 38,5 & 72 \\
2.00 & 26,8 & 37,5 & 73 \\
3.00 & 26,0 & 37,0 & 73 \\
4.00 & 25,8 & 36,0 & 74 \\
5.00 & 25,7 & 36,0 & \\
6.00 & 25,5 & 36,0 & $\mathbf{5 6}, 0$ \\
\hline Rata- & $\mathbf{2 8 , 5}$ & $\mathbf{3 8 , 2}$ & \\
rata & & & \\
\hline & & & \\
\hline
\end{tabular}

TABEL 2. HASIL PENGUKURAN HARI KE-9

\begin{tabular}{cccc}
\multirow{2}{*}{$\begin{array}{c}\text { Waktu } \\
(\text { Jam })\end{array}$} & \multicolumn{2}{c}{$\begin{array}{c}\text { Temperatur } \\
\left(\mathbf{C}^{\mathbf{0}}\right)\end{array}$} & $\begin{array}{c}\text { Kelembaban } \\
(\%)\end{array}$ \\
\cline { 2 - 3 } & Luar & Dalam & \\
\hline 7.00 & 26,1 & 36,3 & 78 \\
8.00 & 26,9 & 36,5 & 74 \\
9.00 & 27,1 & 37,2 & 70 \\
10.00 & 28,8 & 38,1 & 61 \\
11.00 & 29,0 & 38,4 & 62 \\
12.00 & 30,0 & 38,7 & 61 \\
13.00 & 30,5 & 39,0 & 58 \\
14.00 & 30,7 & 39,1 & 57 \\
15.00 & 30,8 & 38,3 & 55 \\
16.00 & 30,9 & 39,0 & 56 \\
17.00 & 30,0 & 39,1 & 58 \\
18.00 & 30,1 & 39,0 & 59 \\
19.00 & 29,5 & 38,8 & 62 \\
20.00 & 29,5 & 38,8 & 64 \\
21.00 & 29,0 & 38,9 & 66 \\
22.00 & 28,5 & 38,9 & 67 \\
23.00 & 28,0 & 39,0 & 68
\end{tabular}

$\begin{array}{cccc}24.00 & 27,3 & 38,5 & 69 \\ 1.00 & 27,0 & 38,5 & 70 \\ 2.00 & 26,4 & 37,1 & 71 \\ 3.00 & 26,1 & 37,0 & 72 \\ 4.00 & 25,5 & 36,1 & 72 \\ 5.00 & 25,1 & 36,0 & 73 \\ 6.00 & 25,0 & 35,9 & 74 \\ \begin{array}{c}\text { Rata- } \\ \text { rata }\end{array} & \mathbf{2 8 , 2 4} & \mathbf{3 8 , 0 0} & \mathbf{5 6 , 5 0}\end{array}$

TABEL 3. HASIL PENGUKURAN HARI KE-18

\begin{tabular}{|c|c|c|c|}
\hline \multirow{2}{*}{$\begin{array}{l}\text { Waktu } \\
\text { (Jam) }\end{array}$} & \multicolumn{2}{|c|}{ Temperatur $\left(\mathrm{C}^{0}\right)$} & \multirow{2}{*}{$\begin{array}{c}\text { Kelembaban } \\
(\%)\end{array}$} \\
\hline & Luar & Dalam & \\
\hline 7.00 & 26,0 & 36,6 & 79 \\
\hline 8.00 & 27,0 & 36,7 & 75 \\
\hline 9.00 & 28,0 & 37,5 & 70 \\
\hline 10.00 & 29,0 & 38,6 & 62 \\
\hline 11.00 & 29,3 & 38,9 & 61 \\
\hline 12.00 & 30,0 & 38,9 & 62 \\
\hline 13.00 & 30,1 & 39,1 & 58 \\
\hline 14.00 & 30,5 & 39,0 & 60 \\
\hline 15.00 & 30,7 & 38,1 & 55 \\
\hline 16.00 & 30,9 & 38,2 & 56 \\
\hline 17.00 & 31,0 & 38,4 & 58 \\
\hline 18.00 & 30,8 & 38,6 & 60 \\
\hline 19.00 & 30,4 & 38,8 & 64 \\
\hline 20.00 & 29,0 & 38,9 & 66 \\
\hline 21.00 & 29,1 & 39,0 & 67 \\
\hline 22.00 & 28,5 & 39,1 & 68 \\
\hline 23.00 & 28,0 & 38,8 & 69 \\
\hline 24.00 & 27,4 & 38,5 & 70 \\
\hline 1.00 & 27,1 & 38,1 & 71 \\
\hline 2.00 & 26,5 & 37,1 & 72 \\
\hline 3.00 & 26,1 & 37,0 & 73 \\
\hline 4.00 & 25,5 & 36,1 & 73 \\
\hline 5.00 & 25,6 & 36,0 & 73 \\
\hline 6.00 & 25,6 & 36,0 & 73 \\
\hline $\begin{array}{l}\text { Rata- } \\
\text { rata }\end{array}$ & 28,42 & 38,00 & 56 \\
\hline
\end{tabular}

TABEL 4. RATA-RATA HASIL PENGUKURA TEMPERATUR DAN KELEMBABAN

Temperatur $\left(\mathrm{C}^{\circ}\right)$

\begin{tabular}{ccc}
\hline Luar & Dalam & $(\%)$ \\
\hline $\mathbf{2 8 , 3 8}$ & $\mathbf{3 8 , 5}$ & $\mathbf{5 5 , 8}$
\end{tabular}

Penelitian ini dilakukan dengan menggunakan mesin penetas khusus telur ayam dengan kapasistas 50 butir telur satu kali menetaskan. Tentu penelitian ini dilakukan karena kita pahami sudah banyak menggunakan mesin penetas, baik perorangan (masyarakat) maupun industri sekala kecil dan besar. Namun tidak semua pengguna mesin penetas mengetahui betul tentang temperatur dan kelembaban udara yang sesuai dengan telur yang mau ditetaskan, agar proses penetasan berjalan dengan baik dan 
normal. Keberhasilan penetasan telur ayam sangat dipengaruhi oleh temperatur di luar dan dalam serta kelembaban, dimana temperatur yang baik untuk penetasan telur ayam berkisar antara $36^{\circ} \mathrm{C}$ $40^{\circ} \mathrm{C}$, dengan kelembaban relatif berkisar antara 50\%-60\%. Namun untuk mendapatkan temperatur yang merata dan kelembaban yang baik untuk penetasan dibutuhkan penempatan sumber kalor yang terukur dan merata didalam ruang penetasan. Temperatur dan kelembaban sangat erat hubungannya dengan perubahan kalor yang terjadi pada mesin penetas, baik didalam maupun di luar mesin penetas. Semakin tinggi temperatur di luar tentu sangat berpengaruh temperatur di dalam mesin penetas. Beberapa studi literatur telah dilakukan terhadap beberapa penelitian yang berhubungan dengan penetasan telur ayam terutama yang berhubungan dengan temperatur di luar dan dalam serta kelembaban udara pada mesin penetas telur ayam. Temperatur dan kelembaban dalam mesin penetas harus stabil untuk mempertahankan kondisi telur agar tetap baik selama proses penetasan, telur akan banyak menetas jika berada pada temperatur antara 36$40^{\circ} \mathrm{C}$, Embrio tidak toleran terhadap perubahan temperatur yang drastis. Kelembaban didalam mesin penetas sebaiknya diusahakan tetap pada 56 $\%$, Temperatur yang terlalu tinggi akan menyebabkan kematian embrio ataupun abnormalitas embrio, sedangkan kelembaban mempengaruhi pertumbuhan normal dari embrio. Menurut Hartono (2010) yang menyatakan bahwa suhu penetasan alami berkisar antara $37^{\circ} \mathrm{C}-38^{\circ} \mathrm{C}$. Kelembaban udara untuk telur ayam pada saat awal penetasan sekitar 50\%-55\% dan menjelang menetas sekitar 55\% - 60\%.

Pada penelitian ini, dilakukan pertama adalah membuat mesin penetas telur dari bahan tripleks 9 milli kemudian menguji dengan memasukkan telur ayam kampung 10 butir, dimana waktu yang diperlukan untuk penetasan telur secara teoritis sekitar 20-23 hari untuk menetas dengan sempurna (sehat). Pembagian waktu dapat dijabarkan sebagai berikut:

Hari pertama : Pada pagi hari, memasukkan telur yang sudah siap pada mesin dengan sudut sekitar $40^{\circ}$, bagian lancip dibawah dan bagian tumpul di atas dan menutup pintu rapat-rapat sampai dengan hari ke-2. Hari ke-3: Telur diputar 3 kali sehari dipagi hari, siang dan sore (Jangan keluarkan telur dari mesin). Hari ke-4: Buka ventilasi $1 / 4$ bagian selama 15 menit untuk mendinginkan telur setelah itu balik telur. Hari ke5: Buka ventilasi $1 \frac{1}{2}$ bagian dan mulailah membalik telur. Hari ke-6: Buka ventilasi $3 / 4$ bagian dan balik telur. Hari ke-7: Balik telur dan buka ventilasi seluruhnya dan mulailah menyortir telur yang kosong. Hari Hari ke-14: Balik telur dan sortir lagi bibit yang mati (Bibit yang mati akan terlihat cairan atau darah sedangkan yang hidup akan terlihat titik yang bercabang). ke 8 s.d 13: Balik telur dan dinginkan. Hari ke 15 s.d 17: Balik telur dan dinginkan. Hari ke18 : Balik telur dan pastikan mesin masih dalam keadaan tertutup. Hari ke-19 : Telur mulai retak, dan harus menambah kelembaban udara pada mesin tetas dengan cara memperbanyak air pada talang air pendingin yang ada di bawah rak telur. Hari ke-20: Telur sudah menetas. Hari ke-21 : Telur dikeluarkan dari mesin penetas dan dipindahkan ke tempat induk buatan.

Berdasarkan pada proses penetasan tersebut di atas pada penelitian ini, untuk memperoleh proses penetasan yang sempurna (semua telur bisa menetas) dengan baik dan sehat diperlukan suatu kondisi temperatur yang stabil pula yaitu diperoleh rata-rata $38,5^{\circ} \mathrm{C}$ dan kelembaban udara dalam mesin penetas telur diperoleh rata-rata 55,8\%. Mesin penetas telur diberikan temperatur dan kelembaban dalam mesin penetas mulai hari pertama sampai hari ke21 (menetaskan telur) yaitu temperatur $38,5^{\circ} \mathrm{C}$ dan kelembaban $55,8 \%$, dimana temperatur di luar ratarata $28,38^{\circ} \mathrm{C}$.

Waktu paling penting yang perlu menjadi perhatian adalah pada saat dimana proses penetasan memasuki hari ke-17-18, dimana waktu ini diperlukan temperatur dan kelembaban yang betul-betul stabil agar embrio (Dot) dapat menetas dengan baik dan sehat. Jika tempereratur melebihi batas teoritis (36$40^{\circ} \mathrm{C}$ ), maka embrio mudah memecahkan cangkang telur untuk keluar tetapi bahayanya atau dampaknya adalah embrio mudah mati karena kepanasan sehinga terjadi dehidrasi. Demikian pula jika kelembaban melebihi batas teoritis (55-60\%), maka embrio bisa mati di dalam sebelum keluar karena cangkang telur terlalu keras untuk dipecahkan oleh embrio karena terlalu lembab membuat cangkang keras (susah pecah/retak). Jadi proses penetasan yang baik dan sempurna dipengaruhi tiga faktor utama yaitu : 1). Telur harus baik (bibitnya sehat), 2). Temperaturnya harus stabil $\left(36-40^{\circ} \mathrm{C}\right)$, dan 3). Kelembabannya juga harus stabil (55-60\%). Tentu untuk memperoleh telur yang baik (sehat) harus betul-betul mensortir dengan mengetahui cirri-ciri telur yang sehat.

\section{SIMPULAN}

Berdasarkan pada proses penelitian, dimana penelitian ini dengan menguji (mengadakan percobaan 2 kali) percobaan pertama 10 butir telur dan kedua juga 10 butir telur, maka diperoleh kesimpulan sebagai berikut : 
1. Bahwa untuk memperoleh proses penetasan yang sempurna (semua telur bisa menetas) dengan baik dan sehat diperlukan suatu kondisi temperatur yang stabil pula yaitu diperoleh rata-rata $38,5^{\circ} \mathrm{C}$ dan kelembaban udara dalam mesin penetas telur diperoleh rata-rata $55,8 \%$.

2. Mesin penetas telur diberikan temperatur dan kelembaban dalam mesin penetas mulai hari pertama sampai hari ke-21(menetaskan telur) yaitu temperatur $38,5^{\circ} \mathrm{C}$ dan kelembaban $55,8 \%$, dimana temperatur di luar rata-rata $28,38^{\circ} \mathrm{C}$.

3. Jadi perbandingan (ratio) temperatur dan kelembaban yang baik sesuai hasil penelitian yang telah dilaksanakan yaitu $38,5^{\circ} \mathrm{C}$ di dalam sedangkan di temperatur luar $28,38^{\circ} \mathrm{C}$, dan kelembabannya $55,8 \%$.

4. Bahwa proses penetasan memasuki hari ke-1718, dimana waktu ini diperlukan temperatur dan kelembaban yang betul-betul stabil agar embrio (Dot) dapat menetas dengan baik dan sehat. Jika tempereratur melebihi batas teoritis $\left(36-40^{\circ} \mathrm{C}\right)$, maka embrio mudah memecahkan cangkang telur untuk keluar tetapi bahayanya atau dampaknya adalah embrio mudah mati karena kepanasan sehinga terjadi dehidrasi. Demikian pula jika kelembaban melebihi batas teoritis (55-60\%), maka embrio bisa mati di dalam sebelum keluar karena cangkang telur terlalu keras untuk dipecahkan oleh embrio karena terlalu lembab membuat cangkang keras (susah pecah/retak).

\section{DAFTAR PUSTAKA}

[1] F. B. Paimin, Membuat dan mengelola mesin tetas. Penebar Swadaya Grup, 1992.

[2] F. B. Paimin, Membuat dan mengelola mesin tetas. Penebar Swadaya Grup, 1992.

[3] T. Nuryati, M. K. Sutarto, and H. PS, "Sukses menetaskan telur," Penebar Swadaya, Jakarta, 2000.

[4] H. R. Wilson, "Interrelationships of egg size, chick size, posthatching growth and hatchability," World's Poultry Science Journal, vol. 47, no. 1, pp. 5-20, 1991.

[5] M. Rasyaf, Pengelolaan penetasan. Penerbit Yayasan Kanisius, 1984.

[6] A. Wakhid, Membuat Sendiri Mesin Tetas Praktis. AgroMedia, 2016. 